\title{
Considerations on the efficiency of the attack hit in a women's senior volleyball team
}

\section{Sorin GRĂDINARU ${ }^{1}$, Csilla GRĂDINARU ${ }^{2}$}

\begin{abstract}
Introduction: The second division tournament that allows the teams to move up in the first league had, at the start, the 4 best teams in the country. Taken place in Timisoara, between the 12th - 14th of May 2017, this competition gave us the possibility to follow the way in which UVT Agroland Timisoara improve its own attack. This action, according to the statisticians, had the most weight in obtaining the majority of the points.

Aim: This study estaablishes the efficiency of UVT Agroland Timisoara's attack according to the statistics that were taken out during the 3 games when the team played in the tournament. Moreover, this study highlights the gap between the team in question and the rest of the pack. Heterogeneous in terms of age, the hitters represent both young players (15-16 years old) and also experience ones (28-30 years old). This aspect was managed very well by the head coach who created a perfect connection between young and veteran players.

Metods: For carrying out this study we used the following research methods: study of the literature, observational methods, mathematical and statistical methods.

Results: In the wining sets the efficiency of the attack was $68 \%$ and on the losing sets the attack was just $45 \%$. The average winning points of the opposing team is 17 points per set. This is an indication that the team in question (UVT Agroland Timisoara) wins relatively easy the sets that were monitored.

Conclusion: We found that the best efficiency of the attack was $79 \%$ in the winning sets. Second best was $62 \%$ in the sets that were won very hard. And the lowest efficiency was $46 \%$ in the sets that were won relatively easy. This variation of efficiency of the attack is due to some imperfections of the actions prior completing the point, and also the relaxation of the players who think that opposing team is proven to be inferior.
\end{abstract}

Key words: volleyball, efficiency, attack.

\section{Rezumat}

Introducere: Turneul de promovare al Diviziei secunde de volei feminin a reunit la start cele mai bune 4 echipe care urmăreau accederea în prima ligă. Desfăşurată la Timişoara în perioada 12 - 14 mai 2017, această competiţie ne-a dat posibilitatea să urmărim modul în care echipa UVT Agroland Timişoara îşi valorifică atacul propriu. Această acţiune, potrivit statisticilor, are ponderea cea mai mare în totalul punctelor pe care o echipă le obține.

Scop: Acest studiu stabilește eficiența atacului echipei UVT Agroland Timişoara în baza înregistrărilor efectuate în cele 3 jocuri pe care aceasta le-a susţinut în acest turneu. În plus, acest studiu evidenţiază decalajul valoric între echipa observată şi celelalte competitoare. Eterogen din punctul de vedere al vârstei, grupul trăgătoarelor prezintă jucătoare foarte tinere (15-16 ani), cât şi experimentate (28-30 de ani). Acest aspect a fost foarte bine gestionat de antrenorul echipei care a realizat o simbioză reuşită între junioare şi senioare.

Metode: Pentru elaborarea lucrării am utilizat următoarele metode de cercetare: studiul bibliografiei de specialitate, metoda observaţiei, metoda statistico-matematică, metoda reprezentării grafice.

Rezultate: În seturile câştigate eficienţa atacului se situează la 68\%, pe când în seturile pierdute este de doar $45 \%$. Media punctelor pe care adversarul le realizează într-un set câştigat este de 17 puncte, ceea ce ne permite să afirmăm că echipa în studiu îşi adjudecă relativ uşor seturile urmărite.

Concluzii: Am observat cea mai ridicată eficiență a atacului în seturile câştigate uşor (79\%), o eficienţă ridicată (62\%) în seturile câștigate greu și o eficiență mai scăzută (46\%) în seturile câștigate relativ ușor. Această variație a eficienței atacului

\footnotetext{
${ }^{1}$ Associate Professor PhD, West University of Timisoara, Physical Education and Sport Faculty, Romania, sorin.gradinaru@e-uvt.ro

${ }^{2}$ Associate Professor PhD, West University of Timisoara, Physical Education and Sport Faculty, Romania
} 
Timişoara Physical Education and Rehabilitation Journal

se datorează unor imperfecţiuni în acţiunile premergătoare finalizării, cât şi relaxării jucătoarelor în condiţiile în care adversarul se dovedește inferior.

Cuvinte cheie: volei, eficienţă, atac 


\section{Introduction}

The efficiency of subsequent playing actions in the game of volleyball constitutes a study objective for specialists in the field and offers the possibility to intervene during a certain match and after a match in the training process.

In the present study we aimed at observing a women's volleyball team that strives for performance and that is an organizational model at the level of sports games [2].

Being the highest rated women's team in the sports field in Timisoara, UVT Agroland has proven to be on an ascendant trajectory, worthy of appreciation, both at local and national level.

We took the opportunity offered by the fact that the A1 Division promotion tournament took place in Timisoara and we observed the way the team included in our study takes advantage of its own attack actions, an action that according to statistics has the highest balance for the total points scored by a team.

An attack is an offensive action represented by any ball sent over the net to the opponent, by a player while jumping, by hitting the ball with one hand, in such a manner that the player hits the ball while above the superior line of the net [1].

It represents the result of a common effort of the team in the attack phase with the sole purpose of scoring a point for the attacking team [3].

\section{Material and methods}

During the 2016-2017 competition year we have followed the women's volleyball A1 Division Promotion tournament that took place in Timisoara at the „Constantin Jude" Sports Hall (12 - 14 $4^{\text {th }}$ May 2017).

In the development of this paper I used the following methods of research: study of the specialised bibliography, the observation method, the statistics - mathematical method, the graphycal representation method.

We focused on observing the quality of the attack hits for UVT Agroland team in the three matches they played in the tournament.

During the match one can obtain significant data by using the efficiency index [4].

The efficiency coefficient was noted with $\mathrm{W}$ and was calculated with the following formula:

$$
W=\frac{x^{2}+y}{(x+z)^{2}+2 y}
$$

Where:

$\mathrm{x}=$ the attack was finalized, the action was successful, scored point;

$\mathrm{y}=$ the attack was not finalized, it was overtook by the opponent team, the game continued;

$\mathrm{z}=$ the attack was wrong.

The present study wishes to establish the efficiency of the attack for a women's senior volleyball team based on the recordings made during three matches, all matches being decisive for the future of the team and of volleyball in Timisoara as a whole.

We wanted to verify if:

a. the attack efficiency was high in all sets that had been won (easy, relatively easy, or difficult);

b. the attack efficiency differs in the sets that had been won in comparison to the lost sets.

For carrying out this study we used the following research methods:

$>$ study of the literature,

$>$ observational methods,

> mathematical and statistical methods,

$>$ graphical representation methods [3]

\section{Results}

The data we have obtained were structured in three registration documents conceived especially for the object of our study, as follows:

Table I. Match 1 - The results of the match UVT Agroland - CS Rapid București

\begin{tabular}{ccccc}
\hline \multicolumn{5}{c}{ UVT Agroland - C.S. Rapid Bucureşti } \\
\hline Set & $x$ & $y$ & $z$ & Score \\
\hline $1^{\text {st }}$ Set & 9 & 16 & 5 & $25-19$ \\
\hline $2^{\text {nd }}$ Set & 10 & 10 & 1 & $25-12$ \\
\hline $3^{\text {rd }}$ Set & 5 & 12 & 2 & $25-18$ \\
\hline
\end{tabular}

$\mathrm{x}=$ the attack was finalized, the action was successful, scored point;

$\mathrm{y}=$ the attack was not finalized, it was overtook by the opponent team, the game continued;

$\mathrm{z}=$ the attack was wrong.

$$
\begin{gathered}
W=\frac{x^{2}+y}{(x+z)^{2}+2 y}=\frac{9^{2}+16}{(9+5)^{2}+2 * 16}=\frac{97}{228} \\
=0,42
\end{gathered}
$$


The efficiency of the attack in the first set was $42 \%$.

$$
\begin{gathered}
W=\frac{x^{2}+y}{(x+z)^{2}+2 y}=\frac{10^{2}+10}{(10+1)^{2}+2 * 10}=\frac{110}{141} \\
=0,78
\end{gathered}
$$

The efficiency of the attack in the second set was $78 \%$

$$
W=\frac{x^{2}+y}{(x+z)^{2}+2 y}=\frac{5^{2}+12}{(5+2)^{2}+2 * 12}=\frac{37}{73}=0,5
$$

The efficiency of the attack in the third set was 50\%.

Table II. Match 2 - The results of the match UVT Agroland - CSM Focșani

\begin{tabular}{ccccc}
\hline \multicolumn{5}{c}{ UVT Agroland - C.S.M. Focşani } \\
\hline Set & $X$ & $y$ & $z$ & Score \\
\hline $1^{\text {st }}$ Set & 11 & 4 & 2 & $25-15$ \\
\hline $2^{\text {nd }}$ Set & 13 & 8 & 0 & $25-12$ \\
\hline $3^{\text {rd }}$ Set & 11 & 8 & 1 & $25-12$ \\
\hline $\begin{array}{c}x^{2}+y \\
=0,72\end{array}$ & $=\frac{11^{2}+4}{(11+2)^{2}+2 * 4}=\frac{125}{173}$
\end{tabular}

The efficiency of the attack in the first set was $72 \%$.

$$
\begin{gathered}
W=\frac{x^{2}+y}{(x+z)^{2}+2 y}=\frac{13^{2}+8}{(13+0)^{2}+2 * 8}=\frac{177}{185} \\
=0,95
\end{gathered}
$$

The efficiency of the attack in the second set was $95 \%$.

$$
\begin{gathered}
W=\frac{x^{2}+y}{(x+z)^{2}+2 y}=\frac{11^{2}+8}{(11+1)^{2}+2 * 8}=\frac{129}{160} \\
=0,8
\end{gathered}
$$

The efficiency of the attack in the third set was $80 \%$.

Table III. Match 3 - The results of the match UVT Agroland - Universitatea Cluj

\section{UVT Agroland - Universitatea Cluj}

\begin{tabular}{ccccc}
\hline Set & $X$ & $y$ & $z$ & Score \\
\hline $1^{\text {st }}$ Set & 11 & 13 & 2 & $25-21$ \\
\hline $2^{\text {nd }}$ Set & 10 & 15 & 5 & $20-25$ \\
\hline $3^{\text {rd }}$ Set & 8 & 17 & 1 & $25-15$ \\
\hline $4^{\text {th }}$ Set & 16 & 20 & 5 & $25-23$ \\
\hline
\end{tabular}

$$
\begin{gathered}
W=\frac{x^{2}+y}{(x+z)^{2}+2 y}=\frac{11^{2}+13}{(11+2)^{2}+2 * 13}=\frac{134}{195} \\
=0,68
\end{gathered}
$$

The efficiency of the attack in the first set was $68 \%$.

$$
\begin{gathered}
W=\frac{x^{2}+y}{(x+z)^{2}+2 y}=\frac{10^{2}+15}{(10+5)^{2}+2 * 15}=\frac{115}{255} \\
=0,45
\end{gathered}
$$

The efficiency of the attack in the second set was $45 \%$.

$$
\begin{gathered}
W=\frac{x^{2}+y}{(x+z)^{2}+2 y}=\frac{8^{2}+17}{(8+1)^{2}+2 * 17}=\frac{81}{115} \\
=0,7
\end{gathered}
$$

The efficiency of the attack in the third set was 70\%.

$$
\begin{gathered}
W=\frac{x^{2}+y}{(x+z)^{2}+2 y}=\frac{16^{2}+20}{(16+5)^{2}+2 * 20}=\frac{276}{481} \\
=0,57
\end{gathered}
$$

The efficiency of the attack in the fourth set was $57 \%$.

The efficiency of the attack in the sets won by the team:

$$
\begin{gathered}
\bar{x}=\frac{0,42+0,78+0,5+0,72+0,95+0,8+0,68+0,7+0,57}{9} \\
=\frac{6,12}{9}=0,68
\end{gathered}
$$

The efficiency of the attack in the set lost by the team:

$$
\begin{gathered}
W=\frac{x^{2}+y}{(x+z)^{2}+2 y}=\frac{10^{2}+15}{(10+5)^{2}+2 * 15}=\frac{115}{255} \\
=0,45
\end{gathered}
$$

$\bar{x}=45 \%$ 


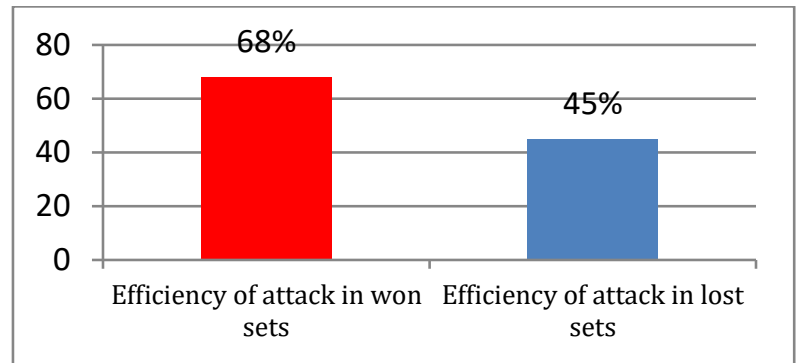

Figure 1. Efficiency of attack

\section{Mean of points lost during the tournament}

$$
\bar{x}=\frac{15+12+12+21+25+15+23+19+12+18}{10}=\frac{172}{10}
$$

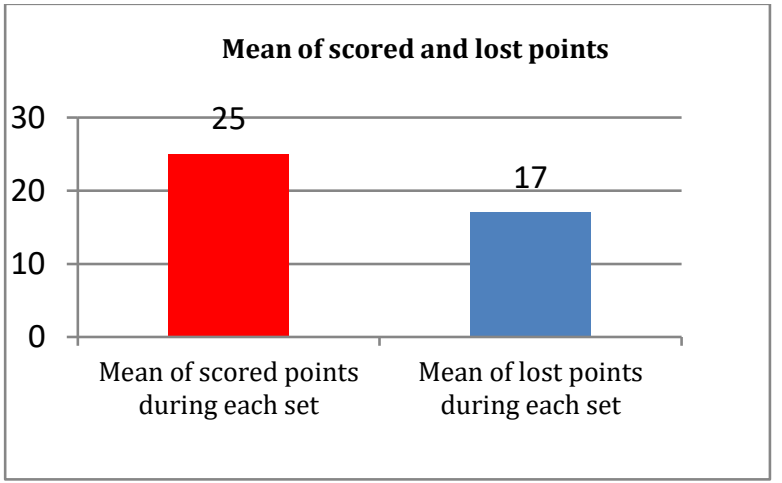

Figure 2. Mean of scored and lost points

Efficiency of attack in sets won easily (under 15 points)

Table IV. Efficiency of attack in clearly won sets

\begin{tabular}{ccccc}
\hline Set & $x$ & $y$ & $z$ & Score \\
\hline $1^{\text {st }}$ Set & 8 & 17 & 1 & $25-15$ \\
\hline $2^{\text {nd }}$ Set & 11 & 4 & 2 & $25-15$ \\
\hline $3^{\text {rd }}$ Set & 13 & 8 & 0 & $25-12$ \\
\hline $4^{\text {th }}$ Set & 11 & 8 & 1 & $25-12$ \\
\hline $5^{\text {th }}$ Set & 10 & 10 & 1 & $25-12$ \\
\hline
\end{tabular}

$$
W=\frac{0,7+0,72+0,95+0,8+0,78}{5}=\frac{3,95}{5}=0,79
$$

The efficiency of attack in clearly won sets was 79\%.

Efficiency of attack in relatively easy won sets (under 20 points)
Table V. Efficiency of attack in relatively easy won sets

\begin{tabular}{ccccc}
\hline Set & $x$ & $y$ & $z$ & Score \\
\hline $1^{\text {st }}$ Set & 9 & 16 & 5 & $25-19$ \\
\hline $2^{\text {nd }}$ Set & 5 & 12 & 2 & $25-18$ \\
\hline \multicolumn{5}{c}{$W=\frac{0,42+0,5}{2}=\frac{0,92}{2}=0,46$}
\end{tabular}

The efficiency of attack in relatively easy won sets was $46 \%$.

Table VI. Efficiency of attack in sets that were difficult to win (over 20 points)

\begin{tabular}{ccccc}
\hline Set & $x$ & $y$ & $z$ & Score \\
\hline $1^{\text {st }}$ Set & 11 & 13 & 2 & $25-21$ \\
\hline $2^{\text {nd }}$ Set & 16 & 20 & 5 & $25-23$ \\
\hline
\end{tabular}

Efficiency of attack in sets difficult to win

$$
W=\frac{0,68+0,57}{2}=\frac{1,25}{2}=0,62
$$

Efficiency of attack in sets difficult to win was $62 \%$.

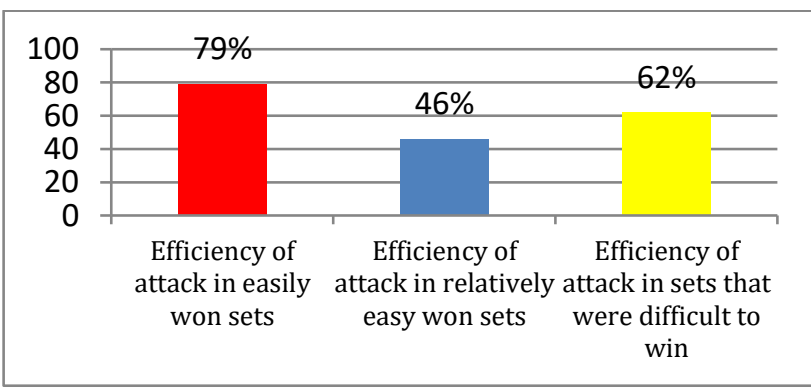

Figure 3. Comparative graphic of the efficiency of attack

\section{Discussions}

This study shows a gap between our team and other teams enrolled in the tournament. Benefiting from high potential attack players (from both lines), shown to good advantage by an experimented Setter, the team included in this study did not meet important resistance from their opponents, which for the team meant achieving their goal, mainly qualifying for the A1 Division in Romanian volleyball.

Heterogeneous when it came to age, the Hitter's group was formed by very young players (15-16 years old), as well as experimented players (28-30 
years old). This aspect was very well managed by the team coach that carried through a great symbiosis between juniors and seniors.

In the sets won by the studied team the efficiency of attack was $68 \%$, while in the sets lost it was of only $45 \%$. The mean for the points scored by the opponents during a won set was 17 , which can lead to the conclusion that the studied team has the ability of winning sets relatively easily.

Recent studies addresses similar results [5,6].'

These studies give us the posibility to identify waus of intervention in anihilation of weaknesses and capitalizing on strengths of the players.

\section{Conclusions}

The highest efficiency rate for the attack was observed in the case of sets that the team has won easily (79\%), a high efficiency rate $(62 \%)$ for sets that were more difficult to win, and a lower efficiency rate $(46 \%)$ for the sets that were relatively easily won. This variation for the efficiency rate is due to certain imperfections in the actions before the finalization, and due to the fact that the players seemed to be more relaxed in front of an opponent that proved to be inferior to their team.

\section{References}

1. Bâc O. (1999). Volleyball, Editura Universităţii din Oradea, 129-140.

2. Ciosici D. (2003). Metodologia cercetării știinţifice, Editura Mirton, Timişoara, 17-32.

3. Grădinaru S., Mergheş P. (2010). Volei. Tehnică - Tactică, Editura Eurobit, Timişoara, 57-63.

4. Păcuraru Al. (1999). Volei. Teorie şi Metodică, Editura Fundației Universitare „Dunărea de Jos”, Galaţi, 237-238.

5. Miskin MA., Fellnigham GW \& Florence LM. (2010). Skill importance in Women's Voleyball, Journal of Quantitative Analysis in Sports, 6 (2), 1-12.

6. Turcanu F., Turcanu D.S. (2106). Study on increasing the efficiency in volleyball, Studia Universitatis Babes - Bolyai, Educatio Artis Gymnasticae, 61 (2), 91-95. 